[VOL. XXVII, NO. 3

\title{
THE LAW OF COSTS
}

By Mark M Orkin Aurora Ontario Canada Law Book 1987 second edition xxiii 400 pages $\$ 90$ (looseleaf)

The first edition of this book was a most welcome addition on the Canadian legal literature horizon; now we are treated to an up-dated version in looseleaf form.

Obviously those who are involved in civil litigation will reap the greatest benefit from this intensive analysis of the law of costs. Civil litigation in Canada, as lawyers know, entails the Charybdis and Scylla of either being awarded or losing court costs: there is a middle way, where the court says, as for example when a novel and new point is raised, that there will be no costs. Ofttimes a potential litigant may get cold feet after being told about the costs aspects of litigation, i.e., what will be owed to his lawyer by way of costs, and what might be the loss in costs if the case goes against him.

The story may be apocryphal or true, but whatever it is, it is well worth recounting: the late George Walsh (who became Mr. Justice Walsh of the High Court of Justice of the Supreme Court of Ontario, and who was the father of the present Mr. Justice Walsh of the same court), is supposed to have said in the course of pleading a case, "Justice - with costs." (See MacDonald, Court Jesters, chapter 12, 153-63, Methuen, Toronto, 1985).

Lawyers doing criminal law work are not as apt to be involved with the issue of costs; however, chapter 15 deals with Costs In Criminal Proceedings. It is not a particularly lengthy discussion, but it does cover a wide swath, and the author has meticulously collected many reported cases dealing with this issue. However, it is strange that this 1987 edition does not make mention of a number of criminal law cases such as Roberts v. Cour de Juridiction Criminelle, Attorney General of Quebec and Clerk of The Crown and Peace (1980) 28 C.R. (3d) 257 (Que. C.A., per Paré, J.A., assault causing grievous bodily harm charge, convicted of common assault, fine and costs); Attorney General Quebec and Director of Montreal Prevention Centre v. Cronier (1981) 23 C.R. (3d) 97 (Que. C.A., per L'HeureuxDubé, J.A.) and Mayrand v. Cronier et al (1981) 23 C.R. (3d) 114 (Que. C.A., per L'Heureux-Dubé, J.A., habeas corpus with certiorari in aid, no costs); Regina v. Davis (1982) 30 C.R. (3d) 378 (Ont. S.C., H.C.J., Montgomery, J., no judicial power under Ontario Legal Aid Act to reduce counsel fee); Regina v. Brown Shoe Co. of Canada Ltd. (No. 2) (1984) 11 C.C.C. (3d) 514 (Ont. S.C., H.C.J., Potts, $\mathrm{J}$., review of law in this area); Regina v. Moodie (1985) 20 C.C.C. (3d) 189 (Ont. C.A., per Morden, J.A., Provincial Offences Act, appeal, costs).

While on the subject of omissions, it is somewhat disconcerting that there is a lack of in-depth discussion of a subject which can be most vexing and troublesome for practising lawyers, namely, the solicitor's lien for unpaid costs, i.e. when and under which circumstances a lawyer may retain a client's file pursuant to the solicitor's lien for unpaid costs: see, for example, Re Fundy Forest Industries Ltd. (1972) 7 N.B.R. (2d) 344 (N.B., S.C., Q.B., per Dickson, J.), and Re Gladstone [1972] 2 O.R. 127 (C.A., per McGillivray, J.A.).

The Preface (at iii) is dated June, 1987, and the Publisher's Note (at PN-1) states that the book contains "the law as of June, 1986". Hence, it is not surprising to find that the author does not deal with the effect of Ontario Rule 49.10 (costs with respect to an offer of settlement) as delineated by the Ontario Court of Appeal in Niagara Structural Steel (St. Catharines) Ltd. v. W. D. Laflamme Ltd. (1987) 58 
O.R. (2d) 773 (and see also Re Fraser Inc. and Aitken et al, Addendum to reasons for Judgment, S.C.O., Toronto Non-Jury, Anderson, J., released January 11, 1989, $\operatorname{Re} 1585 / 85$, unreported at the time of writing).

As for the rest of the book, it discusses and deals with all aspects of the law of costs: party-and-party; solicitor-and-client costs; costs of motions, appeals, Ontario Legal Aid Plan, Supreme Court of Canada, Federal Court, Bankruptcy Court, Provincial (Family and Civil) Court, and Construction Lien Actions; security for costs; assessment of costs; and the tariffs. There are forms and precedents in an appendix.

For the newcomer to law, the various pitfalls and dangers of this issue, and the various costs concepts which may well not have been dealt with in law school lectures (e.g. the Bullock order), are carefully and clearly explained by Dr. Orkin.

Clearly, the book is an indispensable asset for any law library, even for those who do not dabble in litigation, for the elucidation of the law of costs.

One small caveat: the book is aimed primarily at the Ontario law market, largely to the exclusion of other areas such as the eastern and western provinces. At first blush this may not appear to be serious, but in fact it is. One has only to look at a recent Nova Scotia case (unreported at the time of writing), namely, Oatway v. Bannister (Supreme Court of Nova Scotia, Trial Division, heard at Halifax before The Honourable Mr. Justice William J. Grant, in Chambers, on July 7, 1988; decision rendered on December 15, 1988) which involved, as the court says (at page 1), a "taxation of a solicitor and client account arising out of a law suit. There was a contingency agreement. It was settled before trial." The Nova Scotia Rules provide for and deal with contingency agreements. The case was settled by way of a structured settlement. Dr. Orkin's book does not deal with costs as they pertain to contingency agreements and structured settlements. These are serious omissions in this otherwise excellent Ontario-oriented book.

Hugh W. Silverman

Provincial Court Judge

Ontario 